\title{
PENENTUAN PRIORITAS STRATEGI PEMASARAN KOPI ARABIKA (COFFEA ARABICA) DI KABUPATEN BANTAENG DENGAN METODE AHP (ANALITYCAL HIERARCHY PROCESS)
}

\author{
The Determination Of Priorities Of Coffea Arabica Marketing Strategies In BantaengRegency \\ With The Methods AHP (Analitycal Hierarchy Process)
}

\author{
Andi Rizkiyah Hasbi ${ }^{1}$ \\ ${ }^{1)}$ Email: andirizkiyah@stiem.ac.id
}

1) Program Studi Manajemen, Sekolah Tinggi Ilmu Ekonomi Muhammadiyah Palopo

\begin{abstract}
Abstrak
Salah satu cara penentuan mutu kopi adalah dengan uji cita rasa. Konsumen menilai mutu kopi pada saat meminum kopi tersebut. Penelitian ini bertujuan menyusun strategi pemasaran yang diprioritaskan dalam menjalankan usaha kopi arabika Bantaeng. Penelitian ini dilaksanakan di Kabupaten Bantaeng. Pemilihan lokasi dilakukan dengan sengaja atau purposif dengan pertimbangan bahwa di Sulawesi Selatan, Kabupaten Bantaeng merupakan salah satu sumber produk kopi arabika. Pengambilan responden dilakukan dengan cara purposif atau secarasengaja sesuai dengan tingkat kebutuhan data. Responden yang dambil adalah responden yang ahli di bidang pemeliharaan kopi maupun pemasarannya. Adapun analisa data yang digunakan adalah dengan AHP (analytical hierarchy process). Hasil analisis yang telah dilakukan diperoleh yaitu Strategi pemasaran yang diprioritaskan dalam menjalankan usaha kopi arabika Bantaeng yaitu pertama-tama menjaga ketersediaan bahan baku yang sesuai dengan permintaan pasar setelah itu mendukung kemitraan petani dengan aktor pemasar kopi selanjutnya perbaikan sarana dan prasarana pemasar setelah itu pemanfaatan teknologi informasi digunakan untuk memfasilitasi jaringan pasar selanjutnya dilakukan strategi promosi dan prioritas trakhir yaitu penambahan jumlah kedai kopi. Sedangkan penetapan prioritas berdasarkan kelas responden didapatkan hasil bahwa kelas pedagang dan kelas birokrat, lebih memilih kemitraan sebagai prioritas utama, sedangkan untuk kelas petani lebih memproritaskan menghasilkan bahan baku yang baik dan kelas konsumen lebih peduli terhadap perbaikan sarana dan prasarana.
\end{abstract}

Kata kunci : Kopi arabika; AHP; Kemitraan; Promosi; Kedai kopi.

\section{PENDAHULUAN}

\section{A. Latar Belakang}

Tanaman kopi arabika dikembangkan di daerah beriklim subtropis dengan ketinggian 700-1700 meter di atas permukaan laut, dengan suhu rata-rata $16-20^{\circ}$ C. Buah kopi arabika umumnya akan matang setelah 8 bulan dari saat pembuahan (Siswoputro, 1993).

Kopi Arabika merupakan jenis kopi tertua yang dikenal dan dibudidayakan di dunia dengan varietasvarietasnya. Kopi Arabika menghendaki iklim subtropik dengan bulan-bulan kering untuk pembungaannya. Di Indonesia tanaman kopi Arabika cocok dikembangkan di daerah-daerah dengan ketinggian antara 800-1500 $\mathrm{m}$ di atas permukaan laut dan dengan suhu rata-rata $15-24^{\circ} \mathrm{C}$. Pada suhu $25^{\circ} \mathrm{C}$ kegiatan fotosintesis tumbuhannya akan menurun dan akan berpengaruh langsung pada hasil kebun. Mengingat belum banyak jenis kopi Arabika yang tahan akan penyakit karat daun, dianjurkan penanaman kopi Arabika tidak di daerah-daerah di bawah ketinggian $800 \mathrm{~m}$ dpl (Sihombing, 2011).

Biji kopi mengandung kafein yang dapat merangsang kerja jantung dan otak sehingga sebagian orang tidak tahan minum kopi. Untuk mengatasi hal tersebut dan dalam rangka meningkatkan konsumsi kopi dunia, telah ditemukan cara pengolahan biji kopi yang dapat menghilangkan kandungan kafein tanpa mengurangi aroma dan rasa khas kopi. Hasilnya adalah minuman kopi yang harum, nikmat dan tidak merangsang (Najiati \& Danarti, 2007).

Potensi kebun Kopi Kabupaten Bantaeng dapat dikembangkan seiring dengan meningkatnya permintaan pasar. Salah satu aspek yang perlu dikembangkan adalah aspek ekonomi dalam pengembangan pasar, di mana pengembangan pasar 
di tingkat desa dan kabupaten masih belum berkembang. Hal ini mungkin disebabkan karena kurangnya informasi pasar, untuk itu perlu adanya pengamatan lingkungan untuk melihat peluang baru bagi masyarakat di Kabupaten Bantaeng. Peluang pemasaran adalah suatu kebutuhan masyarakat untuk meningkatkan pendapatan. Saat ini kopi merupakan salah satu produk andalan perkebunan di Kabupaten Bantaeng, hanya saja kopi yang dihasilkan di Bantaeng tidak dikelola di Bantaeng, melainkan dijual ke Toraja atau ke Makassar, sehingga menjadi branding Kopi Toraja atau Kopi Makassar. Oleh karena itu kopi Arabika yang dihasilkan oleh Kabupaten Bantaeng hendaknya diproduksi di Bantaeng dan dipasarkan di Kota Makassar.

Menurut Tjiptono (2008) promosi adalah suatu bentuk komunikasi yang berusaha menyebarkan informasi, mempengaruhi, membujuk, dan mengingatkan pasar sasaran atas perusahaan dan produknya agar bersedia menerima, membeli, dan loyal pada produk yang ditawarkan perusahaan yang bersangkutan.

Di Kabupaten Bantaeng pada umumnya kopi Robusta panen hijau yang sudah dipecah kulitnya (atau di-peco dalam bahasa Makassar) dihargai Rp 4.000,00 per liter oleh pedagang pengumpul desa, dan kopi Arabika dihargai Rp 6.500,00 per liter.Sementara, biji kopi dari panen merah dihargai Rp 5.000,00 per liter untuk jenis Robusta dan Rp 6.500,00 per liter untuk Arabika.Perbedaan harga di tingkat desa yang hanya Rp 1.000,00 per liter untuk jenis Robusta dan bahkan tidak ada perbedaan harga untuk jenis Arabika. Pada umumnya tidak ada perbedaan spesifik untuk kopi jenis robusta dan arabika yang ada di Bantaeng, baik dari segi harga maupun cara pemanenan. Hanya saja perbedaan yang paling signifikan antara kopi Robusta dan Arabika yaitu dari segi tekstur dan rasa.Untuk kopi Arabika Bantaeng, biji kopi dominan lebih besar dibanding biji kopi dari Enrekang dan Toraja, sedangkan untuk aroma kopi Arabika sangat kuat dengan rasa yang cukup asam.Adapun tujuan dari penelitian ini yaitu strategi pemasaran yang diprioritaskan dalam menjalankan usaha kopi arabika Bantaeng.

\section{B. Tujuan Penelitian}

1. Menyusun strategi pemasaran yang diprioritaskan dalam menjalankan usaha kopi arabika Bantaeng

\section{Manfaat Penelitian}

Manfaat yang akan di berikan dengan adanya penelitian ini adalah sebagai berikut:

1. Manfaat teoritis. Penelitian ini diharapkan dapat memberi masukan yang bermanfaat bagi perusahaan, yaitu mampu menenentukan prioritas pemasaran kopi arabika di Kabupaten Bantaeng
2. Manfaat Praktis. Penelitian ini di harapkan akan memperluas wawasan untuk mengimplementasikan pengetahuan teoritis yang telah di peroleh penulis khususnya dalam bidang pemasaran dalam kondisi nyata.

\section{METODE PENELITIAN}

\section{A. Jenis Penelitian}

Jenis penelitian yang digunakan pada penelitian ini adalah penelitian deskriptif yaitu suatu jenis penelitian yang hanya mendeskriptifkan atau menggambarkan variabel-variabel penelitian apa adanya tanpa melakukan rekayasa-rekayasalainnya.

\section{B. Fokus Penelitian}

Fokus penelitian ini adalah peneliti ingin menenentukan prioritas pemasaran kopi arabika di Kabupaten Bantaeng

\section{Definisi Operasional}

Strategi pemasaran adalah rencana yang menyeluruh terpadu dan menyatu di bidang pemasaran yang memberikan panduan tentang kegiatan yang dijalankan untuk meningkatkan penjualan kopi arabika Bantaeng.

AHP (Analitical Hierarki Process) adalah suatu alat yang digunakan dalam penelitian ini untuk memecahkan suatu masalah dalam pengambilan keputusan

Penentuan prioritas adalah suatu car yang digunakan untutk menentukan startegi pemasaran kopiarabika dikabupaten Bantaeng.

\section{Teknik Pengumpulan Data}

Teknik pengumpulan data yang digunakan pada penelitian ni adalah penelitian langsung dengan menggunakan kuisioner yang dibagikan ke beberapa responden yang ahli di bidang pemeliharaan kopi maupun pemasarannya. Jumlah responden sebanyak 36 orang dari 3 kecamatan 1 kabupaten dan 1 Kota Madya yang ditentukan yaitu kecamatan Pattaneteang, Bonto Tappalang, Kayu Loe, Kabupaten Bantaeng dan Kota Makassar.

\section{E. Analisis Data}

Adapun analisa data yang digunakan adalah dengan menggunakan analisis AHP (analytical hierarchy process) akan berfungsi sebagai alat untuk menentukan strategi mana yang harus diprioritaskan oleh usaha kopi Bantaeng untuk menunjang kegiatan pemasarannya. 


\section{HASIL DAN PEMBAHASAN}

\section{Prioritas Strategi Pemasaran Kopi Arabika di Kabupaten Bantaeng}

Hasil dari penyelesaian manipulasi matriks ratarata kriteria beserta seluruh nila bobot yang diperoleh dapat disusun hierarki Tabel 1 sebagai berikut :

Tabel 1. Grand Strategi Pemasaran Kopi Arabika Bantaeng

\begin{tabular}{|l|l|c|}
\hline No & Grand strategy & $\begin{array}{l}\text { Ranking } \\
\text { strategi } \\
\text { prioritas }\end{array}$ \\
\hline 1 & Penambahan jumlah kedai kopi & 6 \\
\hline 2 & Peningkatan strategi promosi & 5 \\
\hline 3 & $\begin{array}{l}\text { Menjaga ketersediaan bahan } \\
\text { baku yang sesuai dengan } \\
\text { permintaan pasar }\end{array}$ & 1 \\
\hline 4 & $\begin{array}{l}\text { Mendukung kemitraan petani } \\
\text { dengan actor pemasar kopi }\end{array}$ & 2 \\
\hline 5 & $\begin{array}{l}\text { Tekhnologi informasi digunakan } \\
\text { untuk memfasilitasi jaringan } \\
\text { pemasar }\end{array}$ & 4 \\
\hline 6 & $\begin{array}{l}\text { Perbaikan sarana dan prasarana } \\
\text { pemasar kopi }\end{array}$ & 3 \\
\hline
\end{tabular}

Sumber: Data Primer yang Telah diolah, 2016

Prioritas strategi yang disarankan disusun berdasarkan urutan pertama dengan nilai rangking tertinggi sampai dengan urutan terakhir yaitu pertama menjaga ketersediaan bahan baku yang sesuai dengan permintaan pasar. Bahan baku merupakan faktor yang paling berpengaruh dalam proses pemasaran, selanjutnya mendukung kemitraanpetani dengan aktor pemasar kopi kemudian perbaikan sarana dan prasarana pemasar kopi, setelah itu memanfaatkan tekhnologi informasi digunakan untuk memfasilitasi jaringan pemasar, selanjutnya peningkatan strategi promosi dan terakhir penambahan jumlah kedai kopi.

Adapun yang menjadi prioritas pertama dalam pemasaran kopi arabika Bantaeng yaitu menjaga ketersediaan bahan baku yang sesuai dengan permintaan pasar. Ketersediaan bahan baku kopi merupakan hal terpenting yang harus diperhatikan dalam proses pemasaran agar senantiasa mampu memenuhi permintaan konsumen. Hal ini sesuai dengan pendapat Assauri (1999) bahwa pengendalian persediaan bahan baku merupakan suatu kegiatan untuk menentukan tingkat dan komposisi daripada

persediaan, parts, bahan baku dan barang hasil produksi sehingga perusahaan dapat melindungi kelancaran produksi dengan efektif dan efisien. Selain menjaga ketersediaan bahan baku, petani maupun pedagang pengumpul harus memperhatikan kualitas dari kopi Arabika Bantaeng, dimana dalam proses pemetikan biji kopi harusdiperhatiakan cara memetiknya agar kualitas yang dihasilkan lebih baik.

Selanjutnya, proses pemisahan antara biji hijau dan

biji merah, karena bila dipisahkan harganya jauh lebih berbeda dan lebih untung hasilnya. Sementara itu lembaga-lembaga yang terlibat dalam proses pemasaran kopi arabika Bantaeng juga memiliki strategi produk dengan berbagai upaya untuk memperbesar keuntungan yang diterima. Strategi utama yang dilakukan pedagang pengumpul desa dan pedagang pengumpul besar adalah mengumpulkan kopi sebanyak-banyaknya dengan berbagai variasi kualitas dan melakukan sortiran terhadap kopi-kopi yang berkualitas karena jika kopi disortir maka harga akan semakin tinggi, selain itu pedagang pengumpul juga mengolah biji kopi yang tidak diolah oleh petani kopi untuk menambah nilai jual dari kopi tersebut.

Nurhasanah (2006) menyatakan bahwa strategi pemasaran melalui penentuan prioritas adalah perusahaan harus menjaga produksinya agar dapat selalu menyediakan produknya setiap saat konsumen meminta. Dengan kata lain, perusahaan harus menjaga ketersediaan produk dan kualitas produk, sehingga perusahaan tidak membiarkan konsumennya meninggalkan produknya karena produk pesaing lebih mudah diperoleh ketersediaannya. Selanjutnya ditambahkan oleh penelitian Pujiastuti (2008) mengenai Analisis Kebijakan Perusahaan Dalam Pengendalian Persediaan Bahan Baku di PT X menyatakan bahwa aktivitas produksi yang dilakukan PT X terdiri atas tiga bagian yaitu pengadaan bahan baku, produksi dan distribusi ke distributor. Aktivitas produksi dan distribusi barudapat dilakukan setelah perusahaan mendapatkan permintaan dari konsumen, sedangkan pengadaan bahan baku dapat dilakukan tanpa harus menunggu permintaan dari konsumen. Dengan demikian decoupling point pada PT X terletak pada aktivitas pengadaan bahan baku.

Sagita dan Hidayati (2013) menyatakan bahwa untuk mempertahankan atau bahkan meningkatkan pangsa pasar dalam kondisi persaingan ketat, maka produktivitas perlu ditingkatkan sehingga harga relatif kopi menjadi lebih murah dan pada akhirnya daya saing ekspor kopi Indonesia dapat meningkat. Selain itu, perlu diimbangi dengan adanya upaya perbaikan kualitas (mutu) kopi agar sesuai dengan preferensi konsumen dunia. 2. Pemerintah dan swasta hendaknya bekerjasama secara proaktif untuk memantau perkembangan perkopian dunia dan juga berupaya lebih keras untuk meningkatkan konsumsi kopi dalam negeri guna mengurangi ketergantungan terhadap pasar ekspor serta medorong petani agar terlibat dalam program peningkatan kualitas kopi seperti teknologi pembibitan, budidaya dan sosialisasi petik merah.

Strategi prioritas yang kedua adalah mendukung kemitraan petani dengan aktor pemasar kopi.Dengan adanya kemitraan petani dengan pihak pemerintah maupun pihak swasta dapat meningkatkan pendapatan petani maupun pedagang. Dengan ada kemitraan dapat mempermudah proses pemasaran dari hulu ke hilir. Hal ini sesuai dengan pendapat Hafsah (1999) menyatakan bahwa tujuan ideal kemitraan yang ingindicapai dalam pelaksanaan kemitraan secara lebih konkret yaitu (1) meningkatkan pendapatan usaha kecil dan 
masyarakat, (2) meningkatkan perolehan nilai tambah bagi pelaku kemitraan, (3) meningkatkan pemerataan dan pemberdayaan masyarakat dan usaha kecil, (4) meningkatkan pertumbuhan ekonomi perdesaan, wilayah dan nasional, (5) memperluas kesempatan kerja dan (6) meningkatkan ketahanan ekonomi nasional.

Berdasarkan penelitian yang dilakukan Supriatna dan Drajat (2005) menyatakan bahwa kemitraan pemasaran mampu meningkatkan kualitas kopi dan juga efisensi pemasaran. Harga jual petani SL-PHT peserta kemitraan meningkat sebanyak 13,1 persen, yaitu dari Rp. 8.550,- (saluran tradisional) menjadi Rp. 9.670,- (saluran kemitraan). Manfaat lain dari kemitraan terutama kinerja kelompok tani menjadi lebih baik mencakup kegiatan penyuluhan penyediaan modal kelompok dan terbentuknya agroindustri pengolahan kopi skala rumah tangga. Faktor kunci keberhasilan adalah peningkatan mutu kopi dalam kemitraan harus dibarengi dengan pemberian insentif mutu, penyederhanaan saluran pemasaran dan perlu adanya fungsi mediasi lembaga pemasaran seperti PUSKUD.Kasus kemitraan pemasaran kopi dapat dijadikan contoh disebarluaskan ke daerah produsen kopi lainnya.

Selanjutnya ditambahkan oleh penelitian Kesuma dkk (2014) menyatakan bahwa kemitraan yang terjalin antara pemerintah, BUMN pelaksana dan masyarakat melalui Program kemitraan GP3K di DesaTulungrejo Kecamatan Ngantang Kabupaten Malang telah memberikan berbagai dampak positif. Dengan adanya program kemitraan GP3K ini, banyak manfaat yang diperoleh oleh setiap aktor pelaksana, mulai dari petani dengan meningkatnya kesejahteraan melalui produksi pertanian yang bertambah, PT. Pertani (Persero) dengan keuntungan penjualan yang meningkat, hingga pemerintah karena manghambat proses usaha tani, hingga masalah pengembalian biaya garap oleh petani yang sering terlambat. Sehingga dari kesimpulan tersebut penulis memberikan saran diantaranya melalui penambahan jumlah petugas penyuluh lapangan, baik dari pihak PT. Pertani maupun Dinas Pertanian, peningkatan kualitas pembibingan dari aparatur desa melalui Ketua Gapoktan (Gabungan Kelompok Tani), Kaur bidang pertanian dan irigasi, serta peningkatan partisipasi dari tiap-tiap kelompok tani khususnya dalam mengelola usaha tani dan implementasi Program GP3K.

Strategi prioritas yang ketiga yaitu Perbaikan sarana dan prasarana pemasar kopi. Saat ini masih ada beberapa daerah di Kabupaten Bantaeng yang memiliki akses jalan yang kurang baik seperti jalanan yang masih berlubang dan belum di aspal, yang dapat menghambat proses penjualan kopi. Disamping itu petani-petani kopi arabika Bantaeng masih sangat kekurangan alat pengolah kopi sehingga mereka harus membawa kopi mereka ke ibu kota kecamatan untuk mengolahnya sebelum dijual. Dengan dilakukannya perbaikan sarana dan prasarana dapat mempercepat aliran barang ke konsumen, sehingga memperpendek jalurpemasaran.Selain itu dengan adanya sarana seperti alat pengolah kopi dapat mempermudah petani dalam mengolah kopinya dan juga dapat memperkecil biaya yang dikeluarkan petani. Hal ini sesuai dengan penelitian Ningrum (2010) bahwa memiliki teknologi modern akan memberi dampak positif dalam meningkatkan inovasi. Menggunakan teknologi juga akan menguragi waktu kerja dan mempermudah dalam proses produksi, sehingga akan mempersingkat waktu kerja untuk satu produk dan dapat melakukan proses terhadap produk yang lainya.

Sitanggang dan sembiring (2013) menyatakan bahwa kekutan yang dimiliki kopi dari Kabupaten Dairi yaitu lokasi pengembangan kopi dekat dengan Ibukota Propinsi sebagai pintu masuk pasar ekspor Kabupaten Dairi diukur dari ibukotanya yaitu Sidikalang hanya berjarak kurang lebih 150 km dengan ibukota propinsi yaitu Medan. Selain itu kondisi jalan yang relatif bagus antara Sidikalang dan Medan juga mendukung terbukanya pintu ekspor bagi komoditas kopi Kabupaten Dairi. . Akses Transportasi Secara umum, jalur transportasi dalam Kabupaten Dairi dapat digunakan dengan baik, mulai dari jalan antar desa maupun antar kecamatan.Hal ini dapat mempermudah kegiatan mobilitas penduduk dan hasil produksi kopi.Demikian juga jalur transportasi antar Kabupaten Dairi dengan Kabupaten lainnnya telah memadai dan dapat digunakan dengan baik.

Strategi prioritas yang keempat yaitu tekhnologi informasi digunakan untuk memfasilitasi jaringan pemasaran. Dengan adanya tekhnologi informasi akan mempermudah petani dalam mendapatkan infotentang harga kopi dan kemana mereka harus menjual kopi dan dengan begitu dapat membantu meningkatkan pemasaran kopi. Hal ini sesuai dengan penelitian Setiani (2012) menyatakan bahwa Kemajuan teknologi di web membuat bisnis lebih mudah untuk menempatkan iklan untuk target pasar. Mengikuti perkembangan cara terbaru untuk memperoleh pelanggan dan mengimplementasikannya dengan memastikan bahwa solusi e-commerce akan meningkatkan keuntungan, memaksimalkan kontak bisnis, dan menjaga pemilik usaha menyesuaikan diri dengan kebutuhan dan menarik perhatian pelanggan. Selanjutnya ditambahkan oleh Sitanggang dan sembiring (2013) Berkembangnya teknologi informasi dan komunikasi memungkinkan aksesibilitas yang lebih baik bagi petani dan pelaku usaha kopi Kabupaten Dairi untuk dapat memperoleh informasi yang seluas-luasnya guna meningkatkan produksi dan agribisnis kopi.Perkembangan teknologi tersebut seperti munculnya telepon genggam serta internet.Petani kopi dapat menggunakan telepon genggam untuk berkomunikasi lebih mudah dengan rekan usaha seperti pedagang pengumpul. Sementara internet dapat digunakan untuk memperoleh informasi tentang inovasi-inovasi pertanian dan tipstipspertanian guna meningkatkan hasil produksinya 
Strategi prioritas yang kelima yaitu peningkatan strategi promosi. Saat ini, kopi arabika Bantaeng belum menerapkan strategi promosi, hanya saja konsumen tau tentang kopi arabika Banateng hanya dari mulut ke mulut padahal dengan melakukan promosi konsumen akan tau tentang produk kita dan akan berniat untuk membelinya. Hal ini sesuai dengan penelitian Pujiyanto (2003) menyatakan bahwa Di era perdagangan bebas merupakan masa persaingan produsen dalam memasarkan produknya.Produsen menginginkan pada era tersebut produknya dapat diterima masyarakat secara luas.Agar produknya sampai ke konsumen maka perlu informasi yang jelas melalui media periklanan. Kejelasan informasi pada segmen pasar terhadap produk yang diiklankan akan menghasilkan tanggapan positif dari konsumen yang tentunya akan mendapatkan keuntungan bagi produsen.

Siwi (2005) menyatakan bahwa Informasi media periklanan yang lancar dan mudah dipahami oleh masyarakat (konsumen) akan memberikan tanggapan yang positif bagi konsumen. Informasi yang jelas secara visual maupun verbal dan tidak menyinggung perasaan konsumen akan menguntungkan dipihak produsen. Harapan positif di hati masyarakat merupakan tujuan utama produsen dalam menawarkan produknya, sehingga bisa diterima di pasaran. Berbagai cara produsen dalam mempromosikan produknya melalui periklanan diharapkan mendapatkan citra positif konsumen.

Strategi prioritas yang terakhir yaitu penambahan kedai kopi. Untuk penambahan kedai kopi belum terlalu penting dikarenakan stok bahan baku kopi arabika Bantaeng yang masih perlu diperbaiki. Akan tetap penambahan kedai kopi juga berpengaruh terhadap strategi pemasaran. Hal ini sesuai dengan penelitian Arifianti (2009) menyatakan bahwa dampak diberlakukannya strategi bauran produk adalah dapat meningkatkan laba perubahan, dengan kata lain dapat meningkatkan volume penjualan suatu perusahaan. Berdasarkan uraian tersebut di atas dapat dilihat pengaruh strategi bauran produk dengan volume penjualan sangat erat sekali. Dengan melaksanakan strategi bauran produk yang sesuai dalam menghadapi lingkungan yang berubah-ubah (baik lingkungan eksternal maupun lingkungan internal), maka perusahaan akan dapat mengatasi segala macam rintangan atau hambatan yang dihadapi. Selain itu juga perusahaan akan memperoleh volume penjualan produk yang menguntungkan karena penyesuaian yang dilakukan perusahaan sesuai dengan keinginan konsumen atau pelanggan. Hal ini akan menambah jumlah pelanggan atau konsumen sehingga laba atau keuntungan perusahaan akan naik dan tingkat volume penjualan perusahaan akan meningkat.

Soewarso (1996) menyatakan bahwa strategi alternative yang dikembangkan adalah strategi investasi atau pertumbuhan.Implementasi dari strategi pertumbuhan ini adalah penerapan strategi konsentrasi dengan menekankan pada peningkatan tingkat penggunaan produk, strategi perluasan pasar intensif dan integrasi vertical.Analisis regrei dalam rangka mengevaluasi efektifitas bauran pemasran PT. Tirta Megah Cendana menunjukkn bahwa bauran pemasaran ayang dilaksanakan cukup efektif namun kurang efisien.

Hasil penelitian Moghar (2012) mengenai kombinasi VIKOR dan Fuzzy AHP terhadap strategi pemsaran menunjukkan bahwa paling strategi penting adalah strategi Segmentasi. Penelitian ini menggunakan integrasi Vikor dan AHP fuzzy dalam bidang pemasaran. Sebagai arah masa depan, metode pengambilan keputusan lainnya seperti ELECTRE, GTMA dan PC-TOPSIS dapat digunakan di daerah tersebut. Selanjutnya ditambahkan penelitian yang dilakukan Wickramasinghe dan Takano (2009) hasil penelitian menunjukkan bahwa strategi komunikasi proaktif dan strategi isolasi dengan efektif pemasaran strategi promosi yang strategi terbaik yang bisa dilaksanakan untuk meningkatkan pariwisata.

\section{Prioritas Utama Strategi Pemasaran Kopi Arabika Bantaeng berdasarkan Kelas Responden}

Hasil dari penyelesaian manipulasi matriks ratarata kriteria beserta seluruh nila bobot yang diperoleh dapat disusun hierarki Tabel 2 sebagai berikut :

Tabel 2. Prioritas Utama Strategi Pemasaran Kopi Arabika Bantaeng berdasarkan Kelas Responden

\begin{tabular}{|l|l|}
\hline Kelas Responden & $\begin{array}{l}\text { Prioritas Utama Strategi } \\
\text { Pemasaran }\end{array}$ \\
\hline Birokrat & $\begin{array}{l}\text { Mendukung kemitraan petani } \\
\text { dengan actor pemasar kopi }\end{array}$ \\
\hline $\begin{array}{l}\text { Konsumen } \\
\text { Petani }\end{array}$ & $\begin{array}{l}\text { Perbaikan sarana dan prasarana } \\
\text { pemasar kopi } \\
\text { Menjaga ketersediaan bahan } \\
\text { baku yang sesuai dengan } \\
\text { permintaan pasar }\end{array}$ \\
\hline Pedagang & $\begin{array}{l}\text { Mendukung kemitraan petani } \\
\text { dengan actor pemasar kopi }\end{array}$ \\
\hline
\end{tabular}

Sumber: Data Primer yang Telah diolah, 2016

Pada analisa responden perkelas ternyata masingmasing kelas memiliki prioritas utama strategi pemasaran kopi di Bantaeng. Tabel 2 menunjukkan bahwa kelas pedagang dan kelas birokrat, lebih memilih kemitraan sebagai prioritas utama, sedangkan untuk kelas petani lebih memproritaskan menghasilkan bahan baku yang baik dan kelas konsumen lebih peduli terhadap perbaikan sarana dan prasarana. Hal ini terjadi karena latar belakang keseharian mereka yang berbeda-beda.Oleh karena itu untuk mendukung pemasaran kopi Arabika Bantaeng perlu ada kesepakatan pembagian peran dari masing-masing pelaku. 


\section{PENUTUP}

\section{A. Simpulan}

Strategi pemasaran yang diprioritaskan dalam menjalankan usaha kopi arabika Bantaeng yaitu pertama-tama menjaga ketersediaan bahan baku yang sesuai dengan permintaan pasar setelah itu mendukung kemitraan petani dengan aktor pemasar kopi selanjutnya perbaikan sarana dan prasarana pemasar setelah itu pemanfaatan teknologi informasi digunakan untuk memfasilitasi jaringan pasar selanjutnya dilakukan strategi promosi dan prioritas trakhir yaitu penambahan jumlah kedai kopi. Sedangkan penetapan prioritas berdasarkan kelas responden didapatkan hasil bahwa kelas pedagang dan kelas birokrat, lebih memilih kemitraan sebagai prioritas utama, sedangkan untuk kelas petani lebih memproritaskan menghasilkan bahan baku yang baik dan kelas konsumen lebih peduli terhadap perbaikan sarana dan prasarana.

\section{B. Saran}

Berdasarkan hasil, pembahasan dan kesimpulan maka saran yang dapat dikemukakan dalam penelitian adalah Pemerintah kabupaten Bantaeng beserta jajarannya saling berkolaborasi sama dengan pihak swasta, petani, pedagang maupun konsumen untuk menerapkaan strategi yang menjadi prioritas dalam pemasaran kopi arabika Bantaeng.

\section{DAFTAR PUSTAKA}

Siswoputro, P.S., 1993. Kopi Internasional dan Indonesia. Kanisius, Yogyakarta.

Sihombing, L. 2011. Tata Niaga Hasil Pertanian. USU Press. Medan

Najiyati S, Danarti. 2007. Budidaya Kopi dan Penanganan Lepas Panen. Jakarta: Penebar Swadaya.

Tjiptono F. (2008). Strategi Pemasaran: Edisi 3. Yogyakarta : Andi Offset

Assauri, sofyan. 1999. Manajemen Produksi dan Operasi, Edisi Revisi, Lembaga Penerbitan Fakultas Ekonomi Universitas Indonesia, Jakarta

Nurhasanah, N. 2006.Perumusan strategi pemasaran melalui penentuan prioritas trapezoidal fuzzy number (studi kasus industri minuman tradisional). Jurnal teknik industri vol. 8, no. 2, desember 2006: 131-140. Jurusan teknik industri, Universitas Bina Nusantara, Jakarta.

Pujihastuti n., 2008.Analisis Kebijakan Perusahaan dalam Pengendalian persediaan Bahan Baku di PT $X$. Program Sarjana Ekstensi Manajemen Agribisnis Fakultas Pertanian Institut Pertanian Bogor. Bogor.
Arifianti, R. 2009. Peranan Strategi Bauran Produk Terhadap Volume Penjualan Suatu Perusahaan. Diterbitkan di jurnal express ASM Ariyanti. Bandung.

Sagita T., Hidayati D R, 2013.Keragaan Kopi Pasar Domestik Indonesia. Prodi Agribisnis

Hafsah, Mohammad Jafar. 1999. Kemitraan Usaha: Konsepsi dan Strategi. Jakarta: Departemen Pertanian.

Supriatna A., Drajat B., 2005. Pola Kemitraan dalam Peningkatan Efisiensi Pemasaran Kopi Rakyat (Studi Kasus di Kabupaten Malang, Jawa Timur).Bali Besar Pengkajian dan Pengembangan Teknologi Pertanian. Bogor

Kesuma R. P, Hanafi I, Trisnawati. 2014. Kemitraan Pemerintah Swasta Dan Masyarakat Dalam Mewujudkan Ketahanan Pangan Dan Kesejahteraan Petani (Studi pada Kemitraan PT. Pertani (Persero) dan Petani Mitra di Desa Tulungrejo Kecamatan Ngantang Kabupaten Malang). Jurnal Administrasi Publik (JAP), Vol. 2, No. 5, Hal. 777-782.

Ningrum, P. 2010. Analisis Strategi Pemasaran Usaha Jasa Pembuatan Dan Perbaikan Furniture Ud. Suryani furniture, Bogor, Jawa Barat . Program sarjana alih jenis manajemen departemen manajemen fakultas ekonomi dan manajemen institut pertanian bogor. Bogor

Sitanggang J T., Sembiring S. 2013. Pengembangan Potensi Kopi Sebagai Komoditas Unggulan Kawasan Agropolitan Kabupaten Dairi. Dairi.

Setiani, Y. 2012. Pendekatan Strategi Penawaran Promo dalam e-bussiness .Universitas Gunadarma . Jakarta.

Pujiyanto. 2003. Strategi pemasaran produk melalui media periklanan. Nirmana vol. 5 , no. 1 , januari 2003: 96 - 109. Jurusan desain komunikasi visual, fakultas seni dan desain. Universitas kristen petra. Surabaya.

Siwi, R.K. 2005.Analisis strategi promosi untuk meningkatkan volume penjualan buku sekolah pada PT. Macanan Jaya Cemerlang Klaten. Program Studi Ahli Madya. Universitas Sebelas Maret. Surakarta.

Soewarso.1996. Analisis Strategi pemasaran PT. Tirta Megah Cendana Semarang (Suatu Studi Tentang Pengembangan Strategi Pemasaran Perusahaan Air Minum dalam Kemasan). Tesis.Institut Pertanian Bogor. Bogor.

Mohagar A. 2012. A Combined VIKOR - Fuzzy AHP Approach to Marketing Strategy Selection. Business Management and Strategy.ISSN 21576068 2012, Vol. 3, No. 1

Vasantha Wickramasinghe V \& Takano S. 2009. Application of Combined SWOT and Analytic 
Hierarchy Process (AHP) for Tourism Revival Strategic Marketing Planning: A Case of Sri Lanka Tourism. Journal of the Eastern Asia Society for Transportation Studies, Vol.8, 2009. 